\title{
THE STORY OF RAPE: WRONGDOING AND THE EMOTIONAL IMAGINATION
}

\author{
bob Watt*
}

\section{INTRODUCTION}

This is a response to John Gardner's article - "The Wrongness of Rape". ${ }^{1}$ It claims that Gardner is fundamentally or radically wrong; not by attacking his careful and well-constructed argument from the "inside" - by attempting to demonstrate some logical flaw in his argument - but by attacking his world-view. He shows us a world which simply does not accord with reality as perceived in our everyday lives by most, or all, of us. Whilst many philosophers, and certainly most philosophers of law, analyse the world in the way exemplified by Gardner, it is to be hoped that they reserve this analysis to their professional lives and do not make the mistake of thinking that it is connected with reality. For them reason prevails with emotion being relegated to the status of a mere "epiphenomenon"; whilst, for most of us, our emotional life is at least as important as our rational life.

This article is an invitation to Gardner and others to make a "paradigm shift" in the sense proposed by Thomas Kuhn. ${ }^{2}$ Kuhn, in his explanation of the history of cosmology, showed how in order to explain the observed motion of the planets increasingly complicated systems of circular orbits were used (consisting of cycles, epicycles, epi-epicycles and so forth). These complex systems of orbits were used to explain the motion of the planets round the sun because people refused to believe that the planets could move in anything other than perfect circles. However, as the observational data grew, it became clear that no system of circular orbits, no matter how complex, could explain the observations. When Johannes Kepler advanced the work of Nicolas Copernicus, Tycho Brahe and Galileo Galilei and showed that the orbit of Mars could be best modelled by showing that it was elliptical, the

\footnotetext{
* Professor of Law, University of Buckingham, Hunter St, Buckingham MK18 1EG. I am grateful to the anonymous reviewer, and to Professor Roy J Levin for clarification of the purposes of his research. I retain full responsibility for the opinions expressed in this article and for any and all errors.

${ }^{1}$ Herein references are to John Gardner, 'The Wrongness of Rape' in John Gardner, Offences and Defences: Selected Essays in the Philosophy of Criminal Law (OUP 2006). The original article was written by John Gardner and Stephen Shute; original bibliographic details are to be found in Offences and Defences.

2 Thomas Kuhn, The Structure of Scientific Revolutions (U Chic P 1962).
} 
problem was solved. Similarly, it is averred that no system of purely rational explanation, such as that advanced by Gardner, can explain the wrongness of rape. The explanation needs to start from a different position by explicitly including emotion in the explanation.

Gardner's relegation of emotion to a mere "epiphenomenon” (perhaps the prefix is telling) by trying to convince us that our emotional reaction to rape stems from its wrongness "as the mere use of a person" is unconvincing. The thrust of Gardner's argument is Kantian. It may be summarised by saying we rationally assess rape as wrong because it involves the sheer use of a person for another's end (that of the rapist) and sheer use violates the Categorical Imperative. ${ }^{3}$

Daniel Statman, in his short article criticising Gardner's analysis, ${ }^{4}$ points out that it is possible to "use" a person's body in a number of ways which do not involve sex and claims that Gardner's theory of rape is incomplete because it fails to give an account of why using a person is so much worse when that use is associated with sex. ${ }^{5}$ Statman gives an example of a medical student making use of a person's body by creeping into her room whilst she is unconscious and examining her facial structure to revise for his examination. We might consider a dental student who crept in to examine a sleeping patient's teeth in the same way. We would consider the dental student to be at moral fault, for putting gloved hands and dental instruments in a person's mouth without their consent is reprehensible, but we would not consider him to be as evil as the man who crept in and raped his sleeping victim by oral penetration. ${ }^{6}$ We trust that the relevant competent professional bodies would not allow our trainee dentist to enter practice, but we would not expect the wrongdoers to be liable to life imprisonment under s 1 of the Sexual Offences Act 2003 for the simple reason that it is not a sexual offence. It was a simple non-sexual assault and should be punished as such. The reason that rape is so much worse is purely and simply because of the emotional significance of sexual activity. We do not think of coition as a colourless act; coition is often called "making love” because of the central importance of love in our lives. It

\footnotetext{
${ }^{3}$ An alternative account of the wrongness of rape is to be found in John Stanton-Ife, 'Horrific Crimes' in RA Duff and others (eds), The Boundaries of the Criminal Law (OUP 2010). Stanton-Ife's account claims that the wrongness of rape is to be found, not in a Kantian account (or as a transgression of the Millian harm principle), but as a transgression of the boundary which allows the victim to define herself as a person. The nature of that boundary is, it is judged, emotional and accordingly the account in this article equally answers Stanton-Ife's points.

${ }^{4}$ Daniel Statman, 'Gardner on the Wrongness of Rape' (2012) 4 Jrslm Rev Leg Stud $105,10$.

5 Ibid 109.

${ }^{6}$ See Sexual Offences Act 2003, s 1(a).
} 


\section{THE STORY OF RAPE: WRONGDOING AND THE EMOTIONAL IMAGINATION}

is here asserted, and the argument will be developed, that the epitome of human sexuality - the ideal or standard against which every sexual act is measured - is lovemaking and rape is, of course, the negation of lovemaking and it is thus an emotional crime. It is this point which must be explored and explained.

\section{THE STORY OF RAPE}

Gardner tells us a story about "pure rape" - a story which, as he may intend, offends and revolts us, and fills us with compassion for the victim. Gardner may, on the other hand, say that he simply wants to fill us with a sense of having observed wrongdoing and wants to provoke our rational outrage. This will not do, we simply are not like that. The point is explored below.

In Gardner's story his victim is raped whilst she is asleep; the rapist leaves no trace and he is killed immediately he has left her house. She is not harmed in any discernable way by the violation itself. ${ }^{7}$ The malefactor has been killed upon his exit, thankfully depriving him of the opportunity to, for example, publicly boast of his crime, or taunt his victim. ${ }^{8}$ Boasting or taunting would, of course, give rise to direct or indirect harms. ${ }^{9}$ Gardner's story is effective but his analysis leaves out two important factors.

The first exclusion is, of course, deliberate and central to his argument and is conceded here for, like Gardner, we are only interested in the wrongness of rape not in its harmfulness. Gardner excludes in "pure rape" any possibility of harm to the victim and so he has no need to analyse the issue. However this does not close the issue of "harmless rape", but we must first introduce the second, more important, omission.

The second exclusion from Gardner's analysis is less obvious, but it is of the utmost importance. It is the partial exclusion of the reader; the fly on the wall asked to observe these events and to apply his/her moral evaluation to them. Leaving aside whether the reader may be a source of direct harm ("Do

\footnotetext{
${ }^{7}$ Whilst the victims were fully aware of the activities of Anigbugu and Hyung Woo Pyo, there are some common features between Gardner's hypothetical rape and the real rapes discussed in Attorney-General's References (No 73, 75 of 2010, and 03 of 2011) (Michael Anigbugu and others) [2011] EWCA Crim 633. The differences, relating to the women's knowledge of the offence, relate to the harms done. If there is any possible doubt about the harm occasioned by rape, this report is more than sufficient to dispel it.

${ }^{8}$ Gardner (n 1) 5; sets out the hypothetical harmless rape.

${ }^{9}$ For another fictional account of 'sleep -rape' (here induced by a drug) see Alison Greaves, 2022 (Saverge 2012) ch 27 and the emotional effect upon the victim of its later boastful disclosure in ch 34 .
} 
you know what that evil man did to you?”), or indirect harm such as gossiping leading to the loss of her reputation, ${ }^{10}$ the presence of the reader brings the entire analysis down. Gardner has not, of course, wholly excluded his readers; but he has placed them in a hopelessly narrow class; one might describe them as "the philosophy dons on the $\mathrm{X} 5$ ".${ }^{11}$ His readers are implicitly required to step inside his analysis and to abandon the normal human responses felt when a person is confronted with a story of rape. We feel empathy with Gardner's hypothetical victim. As soon as we read of her plight our mind spills away uncontrolled. "Will she find out? What will happen when she finds out? What will she feel when she finds out?" We feel disgust, we feel outrage and we inwardly shudder for the victim.

A possible answer to this rush of emotion would undoubtedly be to say "There, there, dear, dear, don't worry yourself over this. Your emotions are just epiphenomena and, if you just calm down, you will see that you are rationally outraged by the wrongdoing and your emotional response is just empty sounding off." The problem with this view is that it treats much of our personalities as a mere sideshow - a source of amusement or annoyance whilst our rational minds get on with the (supposedly) Important Business of Running the Show. We therefore need to rehabilitate emotion and bring it back to its rightful place as a vital part of the human personality.

\section{THE REHABILITATION OF EMOTION}

The suppression of emotion is often pathological. Jonathan Glover has shown us how totalitarians suppress emotion in order to ensure that their operatives (paramilitaries, the "security services", concentration camp guards and so forth) are able to perform their murderous functions. ${ }^{12}$ When emotional breakthrough occurred and the operatives realised the monstrosity of their actions they became unable to function. Glover cites, for example, circumstances in which the physical and psychological distance between guards and prisoners was diminished and concentration camp guards were unable to send women and children to the gas chambers. ${ }^{13}$ Glover also points

\footnotetext{
10 Apparently a raped woman suffers loss of reputation see Youssoupoff $v$ MGM Pictures (1934) 50 TLR 581.

11 'The man on the Clapham omnibus' is a shorthand for the ordinary reasonable person apparently introduced by Greer LJ in Hall v Brooklands Auto Racing Club [1933] 1 KB 205 (CA). The point is that Gardner's readers do not appear to be ordinary. The X5 is a coach which covers the route between Oxford and Cambridge, perhaps it is used by philosophy dons.

12 See Jonathan Glover, Humanity: A Moral History of the Twentieth Century (Pimlico 2001). In particular see ch 35 'The Attack on Humanity'.

${ }^{13}$ Ibid 346-7.
} 


\section{THE STORY OF RAPE: WRONGDOING AND THE EMOTIONAL IMAGINATION}

out how in circumstances as diverse as the bombing of Cambodia in the late 1960s, the (in)famous Milgram experiment, and the Cuban Missile crisis how an emotional appreciation of the situation did or could restrain people from committing savagery - where "emotional responses to the possible victims came alive" 14 the aggressor stopped. Our emotional understanding of a possible victim's situation acts as a powerful inhibitor upon our aggressive action. We judge the victim of rape by putting ourselves in her emotional position and feel compassion. We understand victims, whether of rape or, as in Glover's examples, by our emotional reaction, not by reason alone.

The sceptic here might say, "no we don't torture people, murder them or rape them for purely prudential reasons. We do not want to be caught, we care what other people say about us, we do not want to invite retaliation.” These are all acceptable prudential reasons and are plainly reasons for (in)action. Alternatively we may start from Gardner's position that these actions are wrong because, for example, they amount to the use of a person for our own ends and we rationally eschew wrongful action. Both of these objections appear to be valid. How can we answer them?

Even when we are not dealing with the pathological suppression of emotion, it is abnormal to ignore our feelings. It is akin to cutting off half of our personality. How can we illustrate and understand this point? At this point Gardner's own storytelling device becomes useful. Suppose that we look at stories of rape. If we deal with stories we may isolate our reaction and thus exclude prudential reasons against transgression. We may, of course still take Gardner's view that the reason we feel ill after considering the stories is that we have judged the action to be wrongful and are feeling the effects of the epiphenomenon. This is doubted, but in order to consider the counterclaim we need to consider some stories of rape.

It is possible that the most vivid and disturbing images of rape in mainstream film or theatre stop short of showing the actual penetration of the victim, but they are singled out by their emotional intensity. The rape of Irene Forsyte by her husband Soames graphically portrayed in the 1967 BBC television adaptation of John Galsworthy's The Forsyte Saga was described in Nyree Dawn Porter's obituary in the following terms:

"The scene in which Soames Forsyte enforces his conjugal rights by raping Irene remains one of the most shocking episodes in television drama. At the time it was broadcast, it provoked a national debate about violence within marriage. 'It was staggering how seriously it

14 Ibid 408. 
was taken,' Nyree Dawn Porter recalled. 'Politicians had televised discussions on whether Soames was right to rape his wife."”15

Thus a fictional, at two removes, account of rape has the potential to raise strong emotional reactions even where actual penetration is shown, the horrible effect can be intensified by the emotional setting. This occurs in the film A Clockwork Orange. ${ }^{16}$ It is judged that the conjunction of the romantic lyric from the Hollywood film Singing in the Rain ${ }^{17}$ amidst the physical and sexual violence of Alex and his droogs' invasion of Home intensifies the emotional impact. ${ }^{18}$ The method of gaining entry to Home, by playing upon the sympathy of the inhabitants for a person supposedly lying injured outside, the use of comedy masks, and most importantly the use of "Singing in the Rain" together with the parody of dancing which amounts to that which Glover calls "a cold joke"19 shows how a story can evoke a strong emotional reaction.

Now the scene has been set we need to perform some more rigorous analysis. Bruno Bettelheim points out that our highest achievement, or the attainment of psychological maturity, is the finding of meaning in our lives. He explains that wisdom (the understanding of what the meaning of one's life may, or ought, to be) does not suddenly spring upon us, but is built up "small step by small step". ${ }^{20}$ Whilst the purpose of his book The Uses of Enchantment: The Meaning and Importance of Fairy Tales explains the role of folk or fairy tales in the growth of children to psychological maturity, it is clear that since people do not live on fairy tales alone, that other sorts of story have an important place in building up an idea of "who do I want to be

\footnotetext{
${ }^{15}$ See the obituary in the Daily Telegraph of 12 April 2001, some 35 years after the first televising of the event. This is available at: 'Nyree Dawn Porter' The Telegraph (London, 12 April 2001)

<http://www.telegraph.co.uk/news/obituaries/1315823/Nyree-Dawn-Porter.html> accessed 11 July 2014.

16 'A Clockwork Orange - Singin in the Rain (Break-in Scene)' (11 June 2008) $<$ http://www.myvideo.de/watch/4409466/a_clockwork_orange_singin_in_the_rain_ break_in_scene> accessed 11 July 2014.

${ }^{17}<$ http://www.youtube.com/watch?v=D1ZyhVpdXbQ> accessed 11 July 2014.

${ }^{18}$ This point about the effectiveness of music as an emotional intensifier is made later in the story where Alex is inadvertently conditioned to be repulsed by music (including his favourite Ode to Joy from the final movement of Beethoven's $9^{\text {th }}$ Symphony) as he is conditioned by the Ludovico technique to refrain from violence.

${ }^{19}$ Glover (n 12) 36-7. Further examples are set out throughout the book.

${ }^{20}$ Bruno Bettelheim, The Uses of Enchantment: The Meaning and Importance of Fairy Tales, (first published 1975, Penguin 1991) 1.
} 


\section{THE STORY OF RAPE: WRONGDOING AND THE EMOTIONAL IMAGINATION}

like?”21 A story is an emotional rehearsal or an armchair walk-through of a situation.

Soames Forsyte, and Alex and the malchiki serve a purpose useful to us in building up a picture of what it is like to be a rapist and affirming to us, as empathic beings who are hurt by another's pain, that we certainly do not want to be like them. Thus when we hear even the word "rape" we, or at least those of us who are not rapists, immediately think of pain, degradation and suffering. We wish to have no part of it. In a sense the Ludovico technique applied to Alex in A Clockwork Orange is an artificial and brutal extension of that which occurs naturally in a person. Alex was forced to watch violent and sadistic films after being injected with drugs to produce nausea and physical revulsion; after repeated exposure to the combination he became conditioned and was revolted by such behaviour despite the fact that, in his earlier life, he had revelled in ultra-violence, the use of the bolshy kickboot and "the old inout” (ie rape). Most of us build up such revulsion naturally. Feeling (at the very least) queasy is, for most people, a natural reaction to stories of rape.

In his work on fairy tales Bettelheim points out that, whilst in reality people are good and bad at the same time, fairy tales do not demonstrate this ambiguity so that children may more easily learn to tell the difference between good and bad character. ${ }^{22}$ Tales for adults are, of course, much richer in moral complexity because we have a much more supple moral imagination; we are able to appreciate that even Alex is not wholly and irredeemably bad. A Clockwork Orange facilitates our mental exploration of some difficult themes just as Gardner's story of the harmless rape and, it is hoped, the stories herein allow us to explore wrongness from the comfort (for everyone) of our chairs.

\section{SOME STORIES OF SEX}

Assuming that the claim regarding the importance of stories as means for exploring not only the rational consequences of an action (the traditional philosophers' "thought experiment") but also the emotional effect of an event or series of events is broadly correct; here we are going to consider some stories of sexual intercourse. Since we are dealing with an emotional subject readers may find that the stories and the analysis are more explicit and deal more openly with sexual matters than is common in legal or philosophical analysis. This cannot be avoided when one deals with sexual crime. Gardner himself averts to this fact when he suggests that such analysis may be

\footnotetext{
${ }^{21}$ Ibid 10.

22 Ibid 9.
} 
"philosophically uncomfortable, not to say, unsafe". ${ }^{23}$ This cannot be correct, thought cannot and should not avoid discomfort; the whole purpose of academic freedom is to discuss the uncomfortable and the "unsafe".

The stories are based upon Gardner's original story. To facilitate writing and reading, let us call the woman "Mary" and the two men with whom, in various circumstances she has intercourse "John1" and "John2". In the variations to this story John1 and John2 engage in other activities; but let us accept that they are the same Johns as in the first stories, but they have not had the prior experiences. The important thing to note is that the Johns vary in one important characteristic perceived by Mary. Since some of the facts are common to the stories we can reduce them to two tales by using the contraction John1/2 for the two men. Once we have set out the stories we can draw out the essential distinctions between John1 and John 2. A consideration of these stories will demonstrate the wrongness of rape and will show that the root of its wrongfulness is to be assessed by the emotional content of the stories. The presence of the necessarily empathic "fly on the wall" (the real emotional human being) is crucial to our understanding of wrongness.
A. John1/2 enters Mary's bedroom after she has taken a sedative which has the side effect of facilitating intercourse. Donning a condom he has intercourse with Mary and leaves. He is killed by a passing bus.
B. Counterfactually John $1 / 2$ who, for some reason, has intimate knowledge of Mary's body and the inside of her house writes a tale on his tablet detailing his entry into Mary's bedroom whilst she is asleep and his intercourse with her in explicit detail. The tale is wholly fictional, but his knowledge of her house and anatomy makes it entirely plausible. On his way to read the tale to her he is killed by a passing bus and his tablet destroyed.

John1 is a tradesman whom Mary has met at the swimming baths whilst dressed only in her skimpy bikini. She needs some maintenance work done on the radiator in her bedroom. She engages John1 to perform the work. This knowledge is sufficient to allow John1 to enter Mary's house whilst she is asleep and to describe her bedroom and her body in sufficient detail to accomplish the projects set out in story A and story B. If John1 had asked Mary to have intercourse with him she would have angrily refused. This explains story A - John1 raped Mary.

In our story B if John1 were to read his tale to Mary, she would believe that she had been raped and would suffer all of the emotional harms

${ }^{23}$ Gardner (n 1) 2. 


\section{THE STORY OF RAPE: WRONGDOING AND THE EMOTIONAL IMAGINATION}

experienced by women who had been raped. Story B is analogous to Gardner's story of the "harmless" or "pure" rape. The rapist's victim in Gardner's story has not come to any physical harm (physical trauma, pregnancy, sexually transmitted infection); the only possible harm she could have suffered is the horror of being raped. However just as we know that Gardner's harmless rape was a story of wrongdoing, we are equally certain that John1's threat to read the story of Mary's rape to her is equally wrong. We are relieved that John1 was thwarted.

John2 is Mary's regular lover. She enjoys making love with John2; they have sex regularly and are contemplating marriage or some other long-term commitment. The events set out in story A were initiated by Mary; she is entranced by the fairy story The Sleeping Beauty ${ }^{24}$ and wishes to have John2 make love to her whilst she is asleep.

However it is here that Story B really comes into its own. Say that John2 and Mary explain to our observer that Mary would find the tale erotic and that Mary wished to have John2 read her the tale as a prelude to making love. Whilst we may think that Mary and John are slightly "kinky", we must accept that people do have fantasies about sex. Certainly one can find sexual fantasy all the way from Gilgamesh ${ }^{25}$ to the meretricious (in both senses of the word) Fifty Shades of Grey. ${ }^{26}$ This includes fantasies of domination and indeed use. The point of "use" is important for Gardner is claiming it is the "use" of another person which constitutes the wrong, Mary wants to be "used" in a controlled sense by John2 so that she feels no responsibility for that which has happened, ${ }^{27}$ whilst she would recoil in horror (and, incidentally, be harmed if she knew what John1 had done, or was planning). In some senses then, "being

\footnotetext{
24 See, eg, Bettelheim (n 20) 225.

25 NK Sandars (tr), The Epic of Gilgamesh (Penguin 1971). See, in particular, the story of Enkidu and Shamhat.

26 EL James, Fifty Shades of Grey (Vintage 2011). Notwithstanding the plodding nature of the plot and the weak characterisation the book is a best-seller. This appears to be a popular genre of fiction for the category of 'erotica' within the fiction index of the popular bookseller Amazon UK, which seems to contain over forty thousand entries; Website accessed 11 July 2014.

27 This point about rape or use fantasies is powerfully made by Nancy Friday in her My Secret Garden (Virago 1976) 108-109. Friday points out that some women fantasise (and the point that it is a fantasy cannot be too strongly emphasised) about rape as a mechanism for losing control and evading responsibility. Friday points out, in the strongest terms, that none of the women she interviewed would want to be raped in reality.
} 
used" is not wrongful. Perhaps all sexual activity is, in some ways "being used", ${ }^{28}$ and it is the emotional context of that "use" which is important.

One can see the story of use in Pauline Réage's L'histoire d'O. ${ }^{29}$ Here, in a story written by a woman, ${ }^{30}$ a fictional heroine voluntarily submits to sexual slavery. Similarly in Captive of Gor, ${ }^{31}$ a woman who is reduced to sexual slavery by extra-terrestrial kidnappers goes on to embrace her state of captivity, ${ }^{32}$ and comes to believe that she was chosen for slavery because of her psychological make-up. In both of these stories, it is the woman's voluntary, subjection to some form of slavery which she then turns around to enslave, in a psychological sense, her enslaver. ${ }^{33}$

${ }^{28}$ The text which comes to mind as a poetic rendition of this fact is Juliet's opening soliloquy from Act 3 Scene 2 of Romeo and Juliet, especially lines 12-16.

${ }^{29}$ Pauline Réage (pseudonym), L'histoire d'O (Corgi 1972).

${ }^{30}$ The precise identity of the author remains controversial. One view is that the author was Dominique Aury. See Geraldine Bedell, 'I Wrote the Story of O' The Guardian (London, 25 July 2004)

<http://www.theguardian.com/books/2004/jul/25/fiction.features3> accessed 11 July 2014. It is also claimed that Dominique Aury is a further pseudonym for Anne Desclos, see 'Story of O: All about Story of O, the French Erotic Novel by Pauline Reage' (1 January 2011) <http://www.storyofo.info/index.html> accessed 11 July 2014. It is clear that there are some differences between the book and Just Jaeckin's cinematic rendition of the story but both highlight the emotional condition of $\mathrm{O}$; possibly the emotional intensity of the film is increased by Pierre Bachelet's atmospheric score. Even alternative musical arrangements of Bachelet's theme have a strong emotional effect - for example Ramachandra Borcar's (pseudonym Ramasutra) rendition on his 1999 album The East Infection.

${ }^{31}$ John Norman (pseudonym) The Captive of Gor (E-reads 1972). John Norman is, in reality, the philosopher John F Lange. Norman's emphasis on the emotional state of his heroine as set out in the opening passage of the book accord with the emphasis on emotion displayed by the author of L'histoire d'O.

${ }^{32}$ It is instructive to consider the view of Robert Nozick on slavery here. Nozick argues in Anarchy, State and Utopia (Basic Books 1974) 331, that a person may rightfully sell themselves into slavery. Could someone willingly become a 'sex-slave' and derive fulfilment from that status? One message - from L'histoire d'O, the Gorean sagas or Nancy Friday - might be 'yes, but only as a matter of fantasy.' Lange has been interviewed on this matter; see Charlie Jane Anders, 'John Norman, the Philosophy Professor Who Created the Barbaric World of Gor' (22 March 2011) $<$ http://io9.com/5783833/john-norman-the-philosopher-who-created-the-barbaricworld-of-gor> accessed 11 July 2014. Readers may care to heed Gardner's warning at Gardner (n 1), text associated with (n 23).

${ }^{33}$ In Just Jaeckin's film The Story of $O$, O and her master, Sir Stefan (or Stephen - it is unclear) fall in love. In the final scene O brands Sir Stefan (as she has been branded) with her initial using a lighted cigar. In Captive of Gor, the heroine's captor 


\section{THE STORY OF RAPE: WRONGDOING AND THE EMOTIONAL IMAGINATION}

The importance of the stories of "O" and "Eleanor (or Elinor) Brinton" (the Captive of Gor) is not that people should be enslaved or that slavery should be seen as an acceptable mode of life but that the books should be seen purely as fantasy - as, in the sense described above and by Bettelheim, - fairy tales. That is to say ways of exploring the emotion of situations. Bettelheim has pointed out that in fairy tales intended for children, good and evil characters are sharply distinguished and polarised; fairies are either wholly good or wholly evil. ${ }^{34}$ Should we be surprised that in fantasies designed for adults the characters are more like ourselves - somewhat ambiguous? They are ways in which we can explore the emotional significance and meaning of being used. As we have seen we can observe the way in which this is emotionally satisfying even if we find it slightly odd. However, the reader or the person in the jury box, our arbiter of morality whom Gardner has omitted from his story, can readily tell the difference between Story B's John1 and John2, as surely as s/he can see the difference between the Johns in Story A.

How can these tales be theorized and brought to bear on an analysis of the wrongness of rape?

\section{MEANING, EMOTION AND EMPATHY}

Here is one explanation. Perhaps it is a little colourful, no apology is offered because the explanation itself illustrates an important point. Words are creatures of reason; they may not be best suited to an explanation of emotion. As Gardner himself points out the experience of rape may be better expressed by means of "drama, poetry, sculpture, and other more purely expressive ... media" ${ }^{35}$ It may be that which is required of the reader is to "grok" the concepts expressed. ${ }^{36} \mathrm{~A}$ more measured explanation which refers to the philosophical, psychological and scientific literature follows.

It is our common experience that sexual intercourse is the most highly emotionally coloured of our everyday actions. The culmination of intercourse - orgasm - has been studied at a physiological level and a working definition

who has boasted that he never pays for a woman but always captures them, recaptures Elinor from a rival and, having made good his escape, voluntarily pays her price.

${ }^{34}$ See Bettelheim (n 20) 9.

${ }^{35}$ Gardner (n 1) 2.

36 'Grok' is the ugly (fictional) Martian word introduced by Robert A Heinlein in Stranger in a Strange Land (Hodder \& Stoughton 1961). It's meaning is explained as 'to understand intuitively or by empathy'. See the entry in the Shorter Oxford English Dictionary ( $5^{\text {th }}$ edn, OUP 2002). The present author's assertion is that we do not need fictional Martians in order to understand intuitively or empathically; it is a fundamental human faculty. 
containing a number of elements common to both males and females has been agreed:

"An orgasm in the human ... is a variable, transient peak sensation of intense pleasure creating an altered state of consciousness usually accompanied by involuntary rhythmic contractions of the pelvic striated ... musculature, often with concomitant ... contractions and myotonia ... ending usually with feelings of ... well-being and contentment" 37

Indeed. By a similar measure the Mona Lisa is the arrangement of pigment on canvas, David is a carved piece of marble, Im Abendrot or the Concierto de Aranjuez are just collections of sounds, and To his Coy Mistress and The Ecstacy are just words.

We simply do not understand intercourse, still less making love or rape, or any of these works of art by simple, or even complex, rational explanations. No doubt an art historian could place Michelangelo's masterpiece precisely in terms of its time and significance in the art of Europe and the world, but that would not be the point. Marvell and Donne, whatever their honoured place in literature, do not speak only to our rational minds; we understand them more fully on an emotional level. Marvell is particularly powerful in To his Coy Mistress where he calls to mind the power of love over death or is it death over love? His poem does not affect us solely or mainly at the level of reason. For that we would need complex statistical evidence relating the ages at which people retire from sexual intercourse, a description of the inactivity of corpses and the process of bodily decay after burial. Marvell's words, and the emotions they inspire, have much more impact. Similarly we can make love without thinking of the "pelvic striated musculature" and probably do so without considering their "involuntary rhythmic contractions". It is suggested that few of us would choose to make love with a person whose attention was fixed on the contractions of their muscles.

${ }^{37}$ Roy J Levin, 'The Physiology of Orgasm' in John P Mulhall and others (eds), Cancer and Sexual Health (Springer 2011) 36. This author's ellipses within the text indicate the omission of gender-specific effects, such as the ejaculation of semen. Levin makes the point, in a personal communication, that the purpose of his research is therapeutic and the reductionism (of which the author may seem to accuse him) is not meant to diminish the significance of emotion in making love. That is not the author's point, and no criticism of Levin is intended. Even when we are able to provide a molecular account of love (or other emotions) we will still understand them best by raw submersion in their effects rather than by titrating some neurotransmitter. The author feels (or groks) that Levin acted kindly in providing explanation of his work in a way which subsumes whatever neural connections are made in his brain. 


\section{THE STORY OF RAPE: WRONGDOING AND THE EMOTIONAL IMAGINATION}

Our emotional engagement with Mary's situation depends upon our correct perception of the situation. Either she is being raped and we feel revulsion or she is engaged in some slightly kinky sex game and, whilst we may not wholly approve of the antics of John2 and Mary, we are likely to feel happy for them. Assuming that we have some sexual experience, and thus know about the "variable transient peak sensation of intense pleasure creating an altered state of consciousness", and the "feelings of well-being and contentment", we might well like to think of an alternative story in which John2 safely arrives at Mary's house, reads her the (fictional) story and then they make love. As the stories have shown we may "slide" up and down the scale of acceptability by considering our emotional reaction to Mary's treatment. At one end of the spectrum we experience a mixture of nausea, outrage, revulsion and sympathy for Mary when we consider that she has been raped (or believes herself to have been raped); whilst at the other we feel a warm glow and hope that John2 and Mary will find lasting love. Perhaps this emotional state is related to the feelings of well-being and contentment we experience after intercourse; the important point being that these feelings are mutually induced by the shared activity of lovemaking and we measure another's experience by our own, real or imagined, emotional standard. ${ }^{38}$ It cannot be doubted that emotional engagement is constitutive of lovemaking (as opposed to, say, paid-for prostitution) and, if we are engaged by a story, whether as a reader of fiction or because we are hearing it from the jury-box, we put out our "emotional tentacles" to make contact with the person we are hearing. Whilst in the jury-box we have the added complication of ascertaining whether the victim is telling the whole truth and nothing but the truth about her experience; we weigh the experience of rape in general (as opposed to a particular instance) in emotional scales. Gardner's article is about the wrongness of rape as a phenomenon rather than about the forensic analysis of a particular incident and here we are engaged in a similar enterprise. We are not concerned with Mary's rape or her lovemaking, we are concerned whether rape is wrong and why it is wrong. We are "reaching out to" or "becoming part of" the community of rape victims or lovemakers through exercising our empathy or emotional imagination - to use Heinlein's ugly neologism for something which is well-understood by us as humans "grokking". Whilst the emotional space occupied by those making love is, without doubt, the easiest to reach for most of us, we have all experienced

\footnotetext{
${ }^{38}$ See eg, Jakob Eklund, Teresia Andersson-Straberg and Eric M Hansen, “'I’ve Also Experienced Loss and Fear”: Effects of Prior Similar Experience on Empathy’ (2009) 50 Scand J Psychology 65.
} 
intense emotional pain at some time in our lives and we can imagine (even if dimly) that pain sliding over into the emotional experience of rape. ${ }^{39}$

We now turn to a more orthodox explanation of the position. The general theme of the analysis herein is based on David Hume's assertion that reason is the slave of the quiet passions. ${ }^{40}$ This is taken to mean that our first evaluation of an occurrence, such as rape, is emotional rather than rational. However Hume wrote this in the eighteenth century and one might say simply that Hume is entitled to his opinion, which is fully consistent with the remainder of his philosophical works and in the same way Gardner is entitled to his view. It is certainly not sufficient to found a successful radical challenge to Gardner's work. The Gardnerian / Kantian would simply say that the author has provided an alternative (and erroneous) view.

Some support for this alternative view is given by the work of Michael Stocker and Elizabeth Hegeman in Valuing Emotions where they further articulate the view that emotions are central to human personality and often provide the foundation of value. ${ }^{41}$ They opine that emotion is fundamental. However, if Hume is correctly taken as suggesting that at the bottom of our thought emotion and reason are so deeply entwined such that he merely thinks that passion is prior to reason because reason itself does not and cannot act as a motivating power, we are left in a position where we simply have to arbitrarily choose between emotion and reason.

To clarify: the Gardnerian would say rape is wrong because using another person as a means to an end is wrong and we react emotionally to the wrongness.

A person taking the position set out here would simply say rape is wrong - it is horrifying, disgusting, vile, on a visceral, emotional level - it freezes our hearts. One might even say that reason is the true epiphenomenon

What we would need to be able to decide between these two positions is some means of showing that a person could, in some circumstances, reason out a course of action but, because of some defect of emotion, could not act upon it. Such a person would conclude that rape was an egregious example of using a person to one's own end (sheer use) and that if this action was universalised everyone would be used as a means and there would be no "kingdom of ends" ... and then go on to question - what would be wrong with that? There is some evidence that people of this sort do exist. This is

\footnotetext{
${ }^{39}$ We could even, if we wished, share the emotional world of Alex DeLarge or John1, but it is to be hoped that we lack the emotional repertoire. If the interpretation of Bettelheim is correct we have decided that we do not want to be the kind of person who rapes another.

${ }^{40}$ David Hume, A Treatise of Human Nature (first published 1738, OUP 1978). See Book 2 Section III Subsection III 'Of the Influencing Motives of the Will'.

${ }^{41}$ Michael Stocker and Elizabeth Hegeman, Valuing Emotions (CUP 1996).
} 


\section{THE STORY OF RAPE: WRONGDOING AND THE EMOTIONAL IMAGINATION}

illustrated by the work of Antonio Damasio whose work in experimental psychology demonstrates the importance of emotion in action. ${ }^{42}$ Damasio examines the lives of two people afflicted by brain lesions in the part of the brain which produces emotional behaviour. ${ }^{43}$ Damasio's examples - Gage and Elliot $^{44}$ - are able to perform extremely complex rational tasks and formulate rational plans of action which, because of their inability to act emotionally they are unable to evaluate and put into action. Elliot, in particular, continued to reason himself into situations which required meticulous planning only to be unable to decide how to act. This type of injury seems to illustrate the truth of Hume's hypothesis that emotions are the driving force of human personality. However it does not seem necessary to go quite this length to illustrate the fact that people manage to reason themselves into positions which are emotionally repellent.

\section{CONCLUSION}

The argument in this article is that, far from emotions being epiphenomena which follow on behind our rational assessment that rape is wrong because it is a sheer use of another person, emotions are right at the forefront of our assessment of wrongdoing. Even though the story of rape which Gardner recounts is one in which harm is expressly precluded, feelings of disgust and outrage are still evoked in the reader. We find the act of rape vile. However if we retain the element of sexual use, but place it in circumstances in which the person wants to be sexually used, we can reverse the entire sense of the story and, even though we might find it rather kinky we can empathise with our lovers.

It is helpful to summarise the main differences between the positions, as they are understood by the present writer, taken by Gardner, Statman, Stanton-Ife and the writer.

Gardner's position is that rape is wrong because it is an example of the sheer use of a person. Our emotional reactions to rape stem from its wrongfulness.

Statman observes that there are gradations of "sheer use" and that Gardner's account fails to explain why rape is any worse than, eg, a secretive and unwanted oral examination. He points out that sexual behaviour is at the root of the distinctive repulsiveness of rape.

\footnotetext{
42 Antonio R Damasio, Descartes' Error: Emotion, Reason and the Human Brain (Avon 1995).

43 As is clear from the title, part of Damasio's work consists of an attack upon Cartesian dualism, Damasio shows that the mind has a physical cause and existence the brain.

44 See Damasio (n 42). In particular Part One of the book.
} 
Stanton-Ife points out that rape (and other crimes) are destructive of personality itself rather than simply the use of a person.

The present author argues that our emotional evaluation of an act is fundamental to our understanding of it. As observers we react differently to stories of people being happily used or abused. Key to our evaluation of this use or abuse is our emotional empathy: we feel warm or sick. The wrongness of rape stems from our natural emotional nausea and from there we proceed to label it as wrong. We may subsequently adopt a variety of accounts to rationalise our feelings - Gardner's is but one well-articulated example.

The idea that the earth (or, in later cosmologies, the sun) was the centre of the universe perfectly circled by the planets comes from a time in which the laws of the universe, both physical and human, were thought to have been ordained by a god. This god's laws were, of course, wholly rational and perfect. Now we know otherwise, it may be time to accept that the irrationality of emotion is sufficient foundation for identifying some kinds of wrong. It is possible that we could trace the origin of the wrongness in those crimes which we identify as mala in se to no more than those things which we find to be emotionally repellent. This conclusion may be surprising to some because since early times philosophers have held the view that reason is the highest form of thought; perhaps it is now time to trust our unique emotional nature a great deal more. 